\title{
4 Physical Weed Control
}

\subsection{Introduction}

Modern no-till cropping depends on herbicides for weed management; therefore, herbicide applications are an important system input. Various estimates of the embodied energy needed to manufacture and distribute herbicides have been developed. Fore, Porter, and Lazarus (2011) suggest that the total energy associated with herbicide application is between 1.4 and $1.5 \mathrm{GJ} \mathrm{ha}^{-1}$, depending on the crop they were assessing.

Unfortunately, herbicide resistance in many weed species is becoming wide spread (Heap, 1997, 2016) and multiple herbicide resistances in several economically important weed species has also been widely reported (Owen, Walsh, Llewellyn, \& Powles, 2007). In time, herbicide resistant weeds may ultimately result in significant yield reductions and grain contamination.

The International Agency for Research on Cancer (IARC), which is part of the World Health Organisation (WHO), has also concluded that glyphosate is probably carcinogenic to humans (Guyton et al., 2015). This announcement has generated considerable debate in the media concerning the use of herbicides. Other authors have also highlighted the potential hazard to human health of long term exposure to herbicides and pesticides (Duke, 2010; Hernández et al., 2013; Mačkić \& Ahmetović, 2011; Peighambarzadeh, Safi, Shahtaheri, Javanbakht, \& Forushani, 2011; Troudi et al., 2012; Wickerham et al., 2012); therefore, there has been growing interest in nonherbicidal control of weeds. The objectives of this chapter are to outlines some of the potential technologies, apart from herbicide application, for weed management. These technologies include: flaming; steam treatment; electrocution; applying electrostatic fields; microwave weed treatment; applying infra-red radiation; applying ultraviolet radiation; using lasers; robotics; and using abrasive weed control techniques.

\subsection{Tillage}

Prior to the introduction of herbicides in the 1940's, weed control was often achieved through tillage (Price \& Kelton, 2011). Tillage techniques include: hand hoeing; scarifying; or ploughing. Tillage physically disrupts plants, preventing them from maturing and setting seeds. Shallow tillage can stimulate seed bank germination, breaking dormancy in some seeds through abrasion of the seed coat and therefore allowing a follow up treatment to better control the emerged weeds. Tillage can also bury seeds deep enough in the soil profile that they do not emerge after germination. 


\subsubsection{Hand Hoeing}

Hand hoeing of weeds has probably been undertaken since agriculture began. Giampietro and Pimentel (1990) assume that adult males can sustain a power output of $90 \mathrm{~W}$, while adult women can sustain a $60 \mathrm{~W}$ power output. They based this assessment on ergonomic studies and a consistent 30\% difference in elite athletic performance between men and women. The average human power output is therefore approximately $75 \mathrm{~W}$.

Amery, Schramm, and Shapiro (1978) present data indicating that hand weed management in sorghum crops, in Central Niger, requires between 400 and 1000 man-hours annually. It has also been shown that humans require approximately 100 $\mathrm{J}$ of food energy to produce $1.0 \mathrm{~J}$ of work. Therefore, the energy required to hand hoe one hectare of land, assuming 400 man-hours for weed control, will be:

$$
\mathrm{E}=400 \times 75 \times 3600 \times 100=10.8 \mathrm{GJ}^{-1}
$$

Based on the same analysis, Giampietro and Pimentel (1991), demonstrate that using animals and machines reduce the required energy (Tab. 4.1).

Table 4.1: Comparison of energy requirements for different weed tillage control systems.

\begin{tabular}{ll}
\hline Power Source & Gross-energy Requirements $\left(\mathrm{G} / \mathbf{h a}^{-1}\right)$ \\
\hline Manpower & 10.8 \\
Oxen & 5.2 \\
6-HP tractor & 3.1 \\
50-HP tractor & 4.1 \\
\hline
\end{tabular}

Source: Giampietro \& Pimentel, 1991

\subsubsection{Mechanical Tillage}

Tillage force, required to draw a plough through the soil, depends on the width of the tine, the penetration depth into the soil, the plough design (i.e. whether it is a chisel plough, disc plough, or mould board plough) the travel speed (Saunders, Godwin, \& O'Dogherty, 2000), the bulk density of the soil and soil internal shearing resistance (Godwin, O’Dogherty, Saunders, \& Balafoutis, 2007; Saunders et al., 2000). Plough draught force increases as all of these parameters increase (Godwin et al., 2007; Saunders et al., 2000).

Traction is associated with the interface between a tyre and the soil and it profoundly influences the energy requirements for tillage. The soil exerts a force on the wheel, which is in response to the torque applied to the drive wheel by the vehicle's 
transmission system and engine (Zoz \& Grisso, 2003). This response, or reaction force, is called the traction force.

As would be expected, the interface between the soil and the drive wheels does not perfectly transfer the tractor's motive force to ploughs. Travel reduction (Zoz \& Grisso, 2003), which has traditionally been called "wheel slip" occurs between surfaces. Travel reduction occurs because of:

- Flexing of the drive wheels

- Slip between the surfaces (rubber and concrete, for example)

- Shear within the soil.

From a power efficiency standpoint, travel reduction represents a power loss caused by a loss in travel speed or distance (Zoz \& Grisso, 2003). In practice, there is always travel loss, but it becomes significant when the vehicle is towing heavy loads or being used for draught work, such as pulling a plough. Traction efficiency is significantly reduced as travel reduction ratio increases (Figure 4.1). The relationship between travel reduction ratio and traction efficiency is described by:

$$
\mathrm{TE}=\frac{a \cdot T R R^{3}+b \cdot T R R^{2}+c \cdot T R R+d}{T R R+\mathrm{e}}
$$

Tabatabaeefar, Emamzadeh, Varnamkhasti, Rahimizadeh, and Karimi (2009) performed an assessment of several tillage systems to determine the input energy needed (Tab. 4.2).

Intense soil disturbance often leads to soil degradation, erosion and loss of productivity (Price \& Kelton, 2011); therefore, modern agriculture is focused on reducing tillage. Therefore, weed management strategies need to be effective, but without engaging the soil.

\subsection{Thermal Weed Control}

Thermal weed control (flaming and steam) applies heat directly to the weed, which quickly raises the temperature of the moisture in the plants cambium cells. The rapid expansion of this moisture causes the cell structure to rupture, preventing nutrients and water from entering the stalk and leaves (Gourd, 2002).

Thermodynamics predicts that energy, in the form of heat, moves along the temperature gradient until all spatial coordinates reach equilibrium. Equilibrium is reached when the temperature gradient disappears from the system.

Heat is transferred by conduction, convection and radiation. Conduction is the transfer of heat between solid/solid interfaces, and within solids. Convection is the 


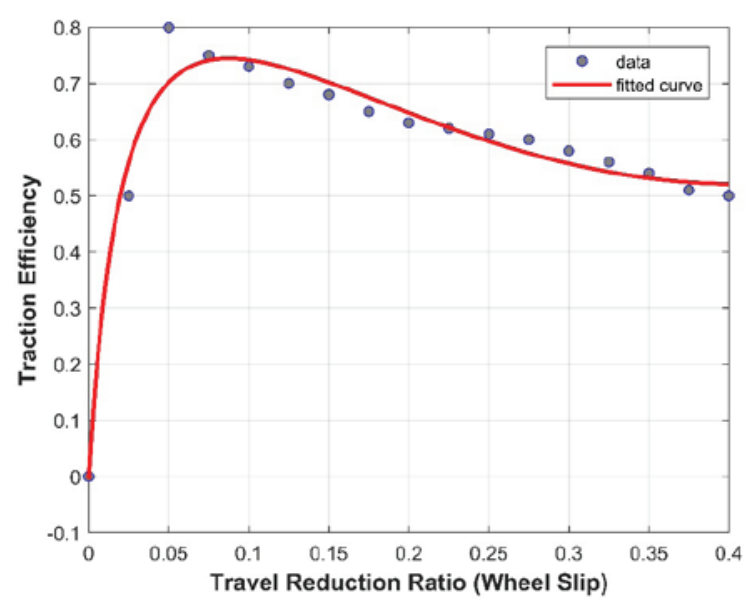

Figure 4.1: Relationship between Travel Reduction Ratio and Traction Efficiency for a MF 6270 MassyFerguson tractor (tested at the Dookie Campus of Melbourne University).

Table 4.2: Comparison of energy requirements for various forms of mechanical tillage (Source: Tabatabaeefar et al., 2009).

\begin{tabular}{ll}
\hline Treatment & Input Energy (G) ha-1 ${ }^{-1}$ \\
\hline Mouldboard plough & 18.71 \\
Chisel plough & 17.62 \\
Cyclo-tiller & 17.67 \\
No-till & 16.33 \\
\hline
\end{tabular}

transfer of heat between an object and its environment due to fluid motion, i.e. a gas or liquid interface with a solid. Radiation is the transfer of heat between bodies through the emission and absorption of electromagnetic energy, without the need for a fluid interface (i.e. as a purely spatial phenomenon). This section will explore how heat can be used to kill weeds.

\subsubsection{Flaming}

Flame weeding is the most commonly applied thermal weed control method. Several kinds of equipment have been developed for weeding, such as tractor-mounted flamers and hand-pushed or handheld devices for weeding around obstacles and for private households. Flaming controls a wide range of weed species (Ascard, 1994), some of which are tolerant or resistant towards herbicides. Flaming gave 72 and $80 \%$ control of common rye and volunteer alfalfa, respectively. Both kochia (Kochia scoparia (L.) 
Roth) and netseed lambsquarter (Chenopodium berlandieri) were also controlled at $65 \%$ (Gourd, 2002).

Ascard (1994) developed dose response relationships between applied energy and weed response. He used three models to determine responses; however, his results are mostly based on the model presented in equation (4.3).

$$
\mathrm{y}=\frac{D}{1+\left(\frac{x}{a}\right)^{b}}
$$

where $\mathrm{y}$ is the response variable of the plant fresh weight or plant number, $\mathrm{x}$ is the liquid petroleum gas (LPG) consumption in $\mathrm{kg} \mathrm{ha}^{-1}$, and $\mathrm{D}$, a and $\mathrm{b}$ are parameters to be determined experimentally. From this model, an $\mathrm{LD}_{50}$ and $\mathrm{LD}_{95}$ were derived for white mustard (Sinapis alba L.) at different plant sizes and densities (Tab. 4.3).

Weed flamers should be shielded, preferably with a long and relatively low roofed shield (Storeheier, 1994) to keep combustion gases close to the ground for as long as possible; the burner angle should be $22.5^{\circ}$ to $45^{\circ}$ to the horizontal.

Tandem burners did not increase effective ground speed compared with single burners (Ascard, 1998). According to Ascard (1994), propane doses of 10-40 kg ha-1 were required to achieve 95\% control of sensitive species with 0-4 leaves, whilst plants with 4-12 leaves required 40-150 kg ha-1. At $49 \mathrm{MJ} \mathrm{kg}^{-1}$, this corresponds to 7.35 GJ ha-1 or $73.5 \mathrm{~J} \mathrm{~cm}^{-2}$.

Species with protected meristems, such as Shepherd's purse (Capsella bursapastoris L.), were tolerant due to regrowth after flaming and they could only be completely killed in their early stages. Annual bluegrass (Poа annua L.) could not be completely killed with a single flame treatment, regardless of developmental stage or propane dose. Considerably lower doses $(40 \%)$ were required in years with higher precipitation compared with a dry year. Because precipitation enhances thermal weed control efficacy, a system which induces high humidity could provide better weed control.

\subsubsection{Steam Treatment}

Steam based weed control has received renewed interest in recent years. The most common and simplest steam applicator is sheet steaming. This involves covering the soil with a thermally resistant membrane, which is sealed at the edges. Steam, which is pumped under the sheet, penetrates the soil's surface layer to kill weeds and their seeds (Gay, Piccarolo, Ricauda Aimonino, \& Tortia, 2010b). A more mobile option is to use a small hooded applicator head, connected to a steam source via a hose, to apply saturated steam to the soil surface (Gay et al., 2010b).

Gay et al. (2010b) tested a hooded applicator with an area of $150 \mathrm{~mm}$ by $150 \mathrm{~mm}$. Their steam generator had a nominal duty cycle of $8.5 \mathrm{~kW}$ with a $1.6 \mathrm{~kW}$ superheater 
Table 4.3: Parameter estimates of regression model for plant number data after flame treatment of white mustard at different plant sizes and densities (Modified from: Ascard, 1994).

\begin{tabular}{lllllll}
\hline $\begin{array}{l}\text { Number of } \\
\text { leaves }\end{array}$ & $\begin{array}{l}\text { Plant density } \\
\left(\text { No. } \mathbf{m}^{-2}\right)\end{array}$ & $\begin{array}{l}\mathbf{D} \text { from equation } \\
(4.18)\left(\text { No. } \mathbf{m}^{-2}\right)\end{array}$ & $\begin{array}{l}\mathrm{a}=\mathbf{L D}_{50} \\
\left(\mathrm{~kg} \mathrm{ha}^{-1}\right)\end{array}$ & $\begin{array}{l}\mathrm{b} \text { from } \\
\text { equation }(4.18)\end{array}$ & $\begin{array}{l}\mathbf{L D}_{95} \\
\left(\mathrm{~kg} \mathrm{ha}^{-1}\right)\end{array}$ & $\begin{array}{l}\mathbf{L D}_{95} \\
\left.(\mathrm{G}) \mathrm{ha}^{-1}\right)\end{array}$ \\
\hline $0-2$ & 195 & 174 & 21.7 & 4.55 & 41.5 & 2.03 \\
$0-2$ & 395 & 342 & 21.7 & 4.55 & 41.5 & 2.03 \\
$2-4$ & 169 & 155 & 38.8 & 4.55 & 74.1 & 3.63 \\
$2-4$ & 365 & 335 & 38.8 & 4.55 & 74.1 & 3.63 \\
$0-2$ & 250 & 207 & 22.1 & 3.87 & 47.3 & 2.31 \\
$0-2$ & 714 & 658 & 22.1 & 3.87 & 47.3 & 2.31 \\
$3-4$ & 265 & 210 & 35.6 & 4.76 & 66.1 & 3.24 \\
$3-4$ & 798 & 607 & 60.4 & 3.01 & 159.5 & 7.82 \\
\hline
\end{tabular}

to deliver $4 \mathrm{~kg} \mathrm{~h}^{-1}$ of superheated steam. It heated an area of soil (100 $\mathrm{mm}$ by $\left.50 \mathrm{~mm}\right)$ to a temperature of $90^{\circ} \mathrm{C}$ or more in 200 seconds. After 300 seconds the entire soil surface under the applicator reached a uniform temperature of $100^{\circ} \mathrm{C}$ (Gay et al., $2010 \mathrm{~b})$. Given that the thermal capacity of water is $4.2 \mathrm{~kJ} \mathrm{~kg}^{-1}{ }^{\circ} \mathrm{C}^{-1}$ and the latent heat of vaporisation for water is $2.26 \mathrm{MJ} \mathrm{kg}^{-1}$, and assuming an initial water temperature of $25^{\circ} \mathrm{C}$, this represents an application energy of $13.5 \mathrm{~kJ} \mathrm{~cm}^{-2}$.

Raffaelli et al. (2016) developed a band steaming system for field work. In their investigation of the system's performance, they used the following relationship for weed survival as a function of steam application:

$$
Y=\frac{D-C}{1+e^{\left\{b\left[\log (x)-\log \left(L D_{50}\right)\right]\right\}}}+C
$$

Where $\mathrm{Y}$ is the weed response (plants $\mathrm{m}^{-2}$ ), D is the upper limit of response (plants $\left.\mathrm{m}^{-2}\right), \mathrm{C}$ is the lower limit of response (plants $\left.\mathrm{m}^{-2}\right), \mathrm{x}$ is the applied steam $\left(\mathrm{kg} \mathrm{m}^{-2}\right)$, and $\mathrm{LD}_{50}$ is the applied steam needed to achieve a $50 \%$ weed mortality rate $\left(\mathrm{kg} \mathrm{m}^{-2}\right)$.

The parameter values from their experimental trials with the system were: $b=2.6$; $\mathrm{C}=-2.8 ; \mathrm{D}=72.5$; and $\mathrm{LD}_{50}=1.0\left(\mathrm{~kg} \mathrm{~m}^{-2}\right)$ (Raffaelli et al., 2016). Based on these values, the $\mathrm{LD}_{90}\left(90 \%\right.$ weed control) for this system was $2.3 \mathrm{~kg} \mathrm{~m}^{-2}$ of steam.

Fennimore and Goodhue (2016) report on an experiment using a commercial steam soil treatment system, which treated $240 \mathrm{~m}^{2} \mathrm{~h}^{-1}$. The system requires $2.6 \mathrm{GJ}$ $\mathrm{h}^{-1}$, which implies an energy requirement of $108.3 \mathrm{GJ} \mathrm{ha}^{-1}$ or $1,083 \mathrm{~J} \mathrm{~cm}^{-2}$. The energy expended during steam treatment varies considerably (Tab. 4.4). Gourd (2002) reports on an experiment where 125 US gallons of steam (water) was used and 3600 square feet $\left(334.4 \mathrm{~m}^{2}\right)$ of weeds. Based on the thermal properties of water, this equates to $365.6 \mathrm{~J} \mathrm{~cm}^{-2}$.

Kolberg and Wiles (2002) reported on their experiments using steam to treat emerged weeds. They discovered that a treatment $890 \mathrm{~kJ} \mathrm{~m}^{-2}$ was necessary to achieve 
Table 4.4: Reported energies used in steam treatments.

\begin{tabular}{|c|c|c|}
\hline Authors & Treatment being applied & $\begin{array}{l}\text { Applied Energy Density } \\
\left(\mathrm{J} \mathrm{cm}^{-2}\right)\end{array}$ \\
\hline $\begin{array}{l}\text { Nishimura, Asai, Shibuya, } \\
\text { Kurokawa, and Nakamura (2015) }\end{array}$ & Soil fumigation & 55,430 \\
\hline Gay et al. (2010b) & Soil fumigation & 13,500 \\
\hline Fennimore and Goodhue (2016) & Soil fumigation & 1,083 \\
\hline $\begin{array}{l}\text { Gelsomino, Petrovičová, Zaffina, } \\
\text { and Peruzzi (2010) }\end{array}$ & $\begin{array}{l}\text { Soil fumigation but with } \mathrm{CaO} \\
\text { addition for extra thermal } \\
\text { activity }\end{array}$ & 781 \\
\hline Gourd (2002) & Weed treatment & 366 \\
\hline Melander and Kristensen (2011) & $\begin{array}{l}\text { Soil fumigation but with band } \\
\text { steaming only }\end{array}$ & 325 \\
\hline Raffaelli et al. (2016) & $\begin{array}{l}\text { Soil fumigation but with band } \\
\text { steaming only }\end{array}$ & 199 \\
\hline Kolberg and Wiles (2002) & Weed treatment & 89 \\
\hline Rask et al. (2013) & $\begin{array}{l}\text { Weed treatment (on hard } \\
\text { surfaces) }\end{array}$ & 75 \\
\hline
\end{tabular}

a similar level of weed control to glyphosate; however, in several cases their steam treatment was not completely effective. Rask, Larsen, Anderson, and Kristofferson (2013) demonstrated that $41.3 \mathrm{GJ} \mathrm{ha}^{-1}$ year ${ }^{-1}$ was required to control weeds on hard surfaces such as foot paths, traffic islands, and path ways. Their observations suggest that 5.5 treatments were needed annually for effective weed control; therefore, the energy required for a single treatment was approximately $7.5 \mathrm{GJ} \mathrm{ha}^{-1}$, or $75 \mathrm{~J} \mathrm{~cm}^{-2}$.

Soil pasteurisation can also be achieved by injecting steam into the soil using gridded steam injectors (Gay, Piccarolo, Ricauda Aimonino, \& Tortia, 2010a; Gay et al., 2010b). This technique could be used as an alternative to soil fumigation, which is commonly applied in high value horticultural crops.

Gay et al. (2010b) developed a scalar index to measure heating efficiency for steam soil heating

$$
I=\frac{1}{V t_{f}} \int_{0}^{t_{f}} \int_{V} T \cdot d V \cdot d t
$$

Where $\mathrm{V}$ is the volume of soil being heated $\left(\mathrm{m}^{3}\right), \mathrm{T}$ is the temperature increase $(\mathrm{K})$, and $t_{\mathrm{f}}$ is the heating time (s). Gay et al. (2010b) applied this index to their steam experiments. Equation (4.5) represents the 4-D average of the temperature change in the soil volume. The performance of sheet steaming varied between about 7.5 and 18 , the hooded applicator varied between about 27 and 37 and the steam injection system varied between 37 and 47 (Gay et al., 2010b). 
Table 4.5: Summary of non-chemical weed control data from Rask et al. (2013).

\begin{tabular}{lll}
\hline Treatment Technology & $\begin{array}{l}\text { Mean number of treatments per year } \\
\text { for effective weed management }\end{array}$ & $\begin{array}{l}\text { Mean energy requirements } \\
(\mathrm{GJ} \text { ha-1) }\end{array}$ \\
\hline Flame & 5 & 34.6 \\
Hot air/flame & 5.5 & 67.9 \\
Steam & 5.5 & 41.3 \\
Hot water & 3 & 43.1 \\
\hline
\end{tabular}

While steam treatment is effectiveat killing weeds, and can achieve some pasteurisation of the soil (Gay et al., 2010a, 2010b), it requires considerable energy investment to create the steam. This is partly due to the inherent limitations of convective heat transfer.

\subsubsection{Hot Water}

Hot water treatment is somewhat linked to steam treatment; however, the initial energy input is less, because there is no need to incur the latent heat requirements of 2.27 MJ kg-1, associated with turning liquid water into steam. In spite of this, some studies have shown that hot water alone is insufficient to provide good weed control and various methods of holding the heat in the plants need to be used. These methods include: multiple applications of hot water; the draping of some kind of thermal blanket behind the applicator, or application of insulating foam along with the hot water (Kempenaar \& Spijker, 2004).

In an assessment of non-chemical weed control for use on hard surfaces, Rask et al. (2013) determined the mean dose of propane gas per year, needed to control weeds, based on different technologies. These are summarised in terms of applied energy per hectare in Table 4.5. From this data it is apparent that hot water is not significantly different from steam treatment, in terms of applied energy.

\subsection{Radiation Systems}

Radiation can be used to overwhelm weeds with energy. Ultimately, radiation based weed control is a form of heat treatment. 


\subsubsection{Infrared Radiation}

Heat kills plants, there being a time-temperature relationship (Levitt, 1980). Radiative heat transfer refers to the transfer of energy by broad spectrum electromagnetic radiation from some adjacent hot object (or from a hot environment) to the heated object. Any object that is above zero degrees Kelvin will radiate energy in the form of electromagnetic photons. The German physicist, Max Planck (1858 - 1947), deduced that the radiation spectral density $(\rho)$ given off from a hot object depended on the wavelength of interest and the temperature of the object. This spectral density can be described by:

$$
\rho=\frac{2 h c^{2}}{\lambda^{5}\left\{\mathrm{e}^{\frac{\mathrm{hc}}{\lambda \mathrm{kT}}-1}\right\}}
$$

Where $\mathrm{h}$ is Planck's constant $\left(6.6256 \times 10^{-34} \mathrm{~J} \mathrm{~s}\right), \mathrm{c}$ is the speed of light, $\lambda$ is the electromagnetic wavelength of interest, $\mathrm{k}$ is Boltzmann's constant $\left(1.38054 \times 10^{-23}\right.$ $\mathrm{J} \mathrm{K}^{-1}$ ), and $\mathrm{T}$ is the temperature in Kelvin. A typical set of spectral distributions for different temperatures is shown in Figure 4.2.

The brightness temperature of a body can be determined by rearranging Planck's equation to find $\mathrm{T}$ for a given spectral density value:

$$
T=\frac{h c^{2}}{\lambda \mathrm{k} \cdot \ln \left(\frac{2 \pi \mathrm{hc}}{\rho \lambda^{5}}+1\right)}
$$

The wavelength at which peak radiation intensity occurs can be found by differentiating Planck's equation and setting the derivative equal to zero (Appendix A). Therefore, the wavelength of peak radiation is determined by:

$$
\lambda_{\mathrm{p}} \approx \frac{\mathrm{hc}}{5 \mathrm{kT}}
$$

Where $\lambda_{\mathrm{p}}$ is the peak radiation wave length $(\mathrm{m})$. At room temperature, or above, the wavelength of peak radiation will be in the micrometre range $(\sim 10 \mu \mathrm{m})$, which is in the Long-wavelength Infrared Band (Table 4.6). The penetration of electromagnetic energy into materials is limited by the wavelength and the dielectric properties of the material (Vollmer, 2004):

$$
\delta=\frac{\lambda \mathrm{p}}{4 \pi \sqrt{\kappa}}
$$

Where: $\delta$ is the penetration depth $(\mathrm{m})$ and $\kappa$ is the relative dielectric constant of the material. The penetration depth of any radiation from objects at room temperature 


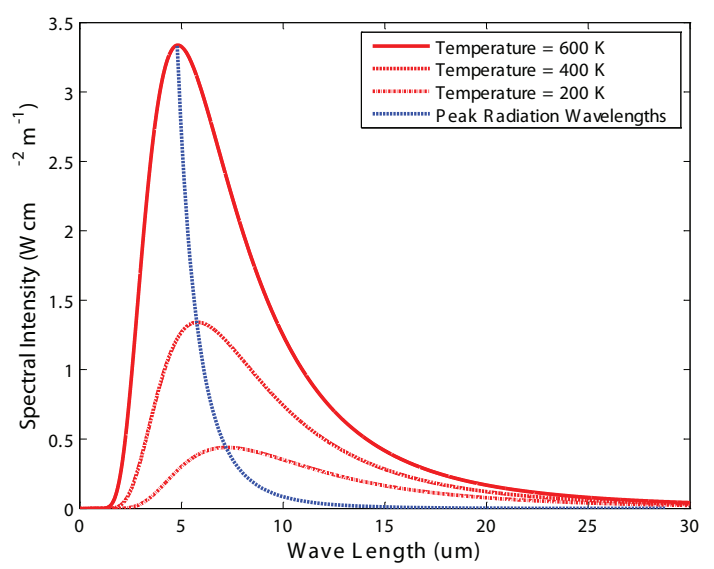

Figure 4.2: Radiative spectral density at different temperatures as a function of temperature and wavelength.

Table 4.6: A commonly used sub-division scheme.

\begin{tabular}{llll}
\hline Division Name & Abbreviation & Wavelength $(\mu \mathrm{m})$ & Temperature (K) \\
\hline Near Infrared & NIR & $0.75-1.4$ & $3,964-2,070$ \\
Short-wavelength Infrared & SWIR & $1.4-3.0$ & $2,070-966$ \\
Mid-wavelength Infrared & MWIR & $3.0-8.0$ & $966-362$ \\
Long-wavelength Infrared & LWIR & $8.0-15.0$ & $362-193$ \\
Far Infrared & FIR & $15.0-1,000$ & $193-3$ \\
\hline
\end{tabular}

or above will be in the nanometre range; therefore, radiative heat transfer must be regarded as a surface phenomenon where further heat transfer from the surface into the material occurs via internal conduction and convection.

The total radiated power can be determined by integrating Planck's equation across all wavelengths for a particular temperature (Appendix B) to yield the StefanBoltzmann equation. The power transferred from an object at one temperature to another object at a lower temperature is given by (Holman, 1997):

$$
q=\varepsilon \sigma A\left(T_{A}^{4}-T_{\mathrm{p}}^{4}\right)
$$

Where $\mathrm{q}$ is the radiation power $(\mathrm{W})$; $\varepsilon$ is the surface emissivity of the radiator material; $\sigma$ is the Stefan-Boltzmann constant $\left(5.6704 \times 10^{-8} \mathrm{~J} \mathrm{~s}^{-1} \mathrm{~m}^{-2} \mathrm{~K}^{-4}\right)$; A is the surface area of the heated object $\left(\mathrm{m}^{2}\right) ; \mathrm{T}_{\mathrm{A}}$ is the temperature of the infrared applicator $(\mathrm{K})$; and $\mathrm{T}_{\mathrm{p}}$ is the temperature of the plants being treated $(\mathrm{K})$. 
Denaturing of plant cell components starts with long term exposure to temperatures of about $40^{\circ} \mathrm{C}$. The fatal impacts of high temperatures on plants have been studied in detail for over a century (Levitt, 1980). In particular, a thoroughly demonstrated empirical relationship between lethal temperature and temperature holding time has been developed by Lepeschkin (1912):

$$
T=79.8-12.8 \cdot \log _{10} Z
$$

Where $\mathrm{T}$ is the lethal temperature $\left({ }^{\circ} \mathrm{C}\right)$, and $\mathrm{Z}$ is the lethal temperature holding time, in minutes (Levitt, 1980).

Infrared radiation systems use gas burners to heat ceramic or metal surfaces, which then radiate infrared energy towards the ground. According to Parish (1990), laboratory investigations identified that a 'medium wave tubular fused quartz infrared emitter' was the most effective for weed control. Infrared burners are not affected by wind, in contrast to flame weeders, and they cover a more closely defined area.

Ascard (1998) discovered that efficacy of flaming and infrared radiation treatment, on emerging seedlings, was similar. For example, when white mustard (Sinapis alba L.) plants were at the 4-leaf stage, propane doses of $8 \mathrm{~kg} \mathrm{ha}^{-1}$ from either flaming or infrared systems merely scorched the edges of the leaves. Propane doses of $30 \mathrm{~kg} \mathrm{ha}^{-1}$ desiccated almost $20 \%$ of the plants, but surviving plants showed vigorous re-growth. One hundred percent weed control required $120 \mathrm{~kg} \mathrm{ha}^{-1}$ of propane for both systems.

Considerably higher temperatures were required under the flamer compared to the infrared radiator. Temperatures of up to $1,350^{\circ} \mathrm{C}$ were recorded in the central blue part of the stationary flamer system; however, the stationary infrared radiator had a maximum temperature of $770^{\circ} \mathrm{C}$ (Ascard, 1998). The ground temperature in both cases was approximately $180^{\circ} \mathrm{C}$ (Ascard, 1998). Ascard (1998) also reports work by Hoffmann who found that infrared radiators cause a higher temperature increase in the upper few millimetres of soil compared to flamers, because radiation heating avoids the convective heat transfer limitations, which are associated with hot air (flame) heating.

For efficient plant destruction, an infrared radiator is required, which produces high energy intensity at a wavelength which is absorbed, rather than reflected or transmitted, by the plant tissues. To kill young white mustard plants, an energy density at ground level of between $200 \mathrm{~kJ} \mathrm{~m}^{-2}$ and $400 \mathrm{~kJ} \mathrm{~m}^{-2}$ (or 20 to $40 \mathrm{~J} \mathrm{~cm}^{-2}$ ) of short wave or medium wave infrared energy are required to severely restrict plant growth (Parish, 1990). These dose rates are similar to those associated with microwave weed control discussed in the previous section; however, because microwaves have a much longer wave length than infrared radiation, the penetration of microwave energy into plants and the soil will be much further.

In several studies, infrared radiators have proved to be inferior compared with flame weeders, but Ascard (1998) and Parish (1990) found the differences in effect was 
dependent on the type of thermal weeder, dose, ground speed, burner height, plant size, plant density and plant species. Their studies also indicate that infrared burners are more likely to suffer from shading interference in dense vegetation compared with flame weeders that cause turbulence and thereby expose more leaves to the flame. This shading effect is linked to the shallow penetration of infrared radiation into most dielectric materials. Because microwave energy has a much longer wave length than infrared energy, microwave weed control is less vulnerable to shading, than other radiation systems, including ultraviolet radiation.

\subsubsection{Ultraviolet Radiation}

The wavelength of ultraviolet (UV) radiation lies between 100 and $400 \mathrm{~nm}$ and is thus outside the visible range. UV rays can be separated into three groups on the basis of wave length: UV-A (320 to $400 \mathrm{~nm}$ ), UV-B (280 to $320 \mathrm{~nm}$ ), and UV-C (100 to $280 \mathrm{~nm}$ ). When plants are irradiated with UV, almost all energy is absorbed in the outermost 0.1- to 0.2-mm layer of the plant tissue. This results in heating of the plant tissue and thus can have effects similar to the damage to plants from flame weeding (Andreasen, Leif, \& Jens, 1999).

Andreasen et al. (1999) irradiated four weed species at two different leaf stages and two crops at one leaf stage with ultraviolet light from a water cooled $2.35 \mathrm{~kW} \mathrm{UV}$ lamp. The weed species were: annual bluegrass (Poa annua L.); common groundsel (Senecio vulgaris L.); shepherd's purse (Capsella bursa-pastoris (L.) Medicus); and small nettle (Urtica urens L.). The crop species were: canola (Brassica napus L. ssp. napus); and pea (Pisum sativa L.). Plants were treated in a laboratory with the UV lamp placed as close as possible to the plant canopy without touching it (about $1 \mathrm{~cm}$ above). Plant parts close to the lamp received more radiation than parts farther away. After irradiation, the above-ground fresh weight was measured after the plants were withered, but before re-growth commenced from undamaged buds.

Andreasen et al. (1999) used the following model to fit their data:

$$
Y=\frac{D-C}{1+e^{\left\{b\left[\log (x)-\log \left(L D_{50}\right)\right]\right\}}}+C
$$

Where $\mathrm{Y}$ is the fresh weight yield to a UV dose of $\mathrm{x}\left(\mathrm{GJ} \mathrm{ha}^{-1}\right)$. D is the upper limit of fresh weight and $\mathrm{C}$ is the lower limit $\left(\mathrm{g} \mathrm{pot}^{-1}\right)$, and $\mathrm{b}$ and $\mathrm{LD}_{50}$ are determined experimentally. Table 4.7 lists the dose response parameters from their experiemnt. Smaller plants are more susceptible to ultraviolet radiation than larger plants, as indicated by their $\mathrm{LD}_{50}$ 's, which are somewhat similar in magnitude to both infrared and microwave radiation, described earlier.

Andreasen et al. (1999) observed re-growth after irradiation, which suggests that more than one treatment would be necessary to obtain efficient weed control. They also deiscovered that the distance between the source of UV radiation and the target 
plants played an important role: increasing the distance from just above the canopy to $17 \mathrm{~cm}$ increased the required dose almost two-fold (Andreasen et al., 1999).

\subsubsection{Lasers}

Light Amplification through Stimulated Emission of Radiation (Laser) is commonly used for cutting industrial materials, surgery, wood cutting, and for research. Laser creates coherent, monochromatic light, which concentrates a large amount of energy into a narrow, non-spreading beam (Heisel, Schou, Christensen, \& Anderson, 2001). Recently, UV (355 nm), visible (532 nm), IR (810 nm), and $\mathrm{CO}_{2}(1064 \mathrm{~nm})$ lasers have been used to cut the stems of weeds, including perennial ryegrass (Lolium perenne L.) (Heisel et al., 2001).

Mathiassen, Bak, Christensen, and Kudsk (2006) investigated the effect of laser treatment on common chickweed (Stellaria media), scentless mayweed (Tripleurospermum inodorum), and canola (Brassica napus). Effective treatment requires the laser to be focused onto the apical meristem of the plants (Mathiassen et al., 2006). Several machine vision based systems have been explored to achieve accurate placement of the laser spot onto weed plants (Mathiassen et al., 2006). Another technique is to move the laser beam back and forth as the system moves forward to achieve good ground coverage. In all cases, it is essential that the laser beam intercepts the weed plant in a favourable way that causes damage to the stem. Proper laser focusing is difficult to achieve in practical terms.

Heisel et al. (2001) found that applying between 0.9 and $2.3 \mathrm{~J} \mathrm{~mm}^{-2}$ from a $\mathrm{CO}_{2}$ laser, when applied below the meristem, resulted in a $90 \%$ or more reduction in weed biomass, in common lamb's quarters (Chenopodium album) and wild mustard (Sinapis arvensis), respectively. Mathiassen et al. (2006) developed a response equation for laser weed treatment of the form:

$$
Y=\frac{D-C}{\left.1+e^{\left[2 b\left(\log \left(L D_{90}\right)+\frac{1.099}{b}-\log (x)\right)\right.}\right]}+C
$$

Where $\mathrm{Y}$ is the fresh weight yield to a UV dose of $\mathrm{x}\left(\mathrm{J} \mathrm{mm}^{-2}\right), \mathrm{D}$ is the upper limit of fresh weight, $C$ is the lower limit, and $b$ and $\mathrm{LD}_{90}$ are determined experimentally. Their results indicate that the efficacy of laser weed control depends on the weed species, wavelength, exposure time, spot size and laser power (Tab. 4.8). As with all radiation weed control methods, efficacy increases with power and exposure time; however, in the case of laser based weed control, spot diameter also affects efficacy. The most efficient system was the $5 \mathrm{~W}, 532 \mathrm{~nm}$ laser with a $1.8 \mathrm{~mm}$ spot diameter (Mathiassen et al., 2006). 
Table 4.7: Summary of regression parameters from the estimated dose-response curves (Modified from: Andreasen et al., 1999).

\begin{tabular}{llllllll}
\hline \multirow{2}{*}{ Species } & $\begin{array}{l}\text { Growth } \\
\text { stage }\end{array}$ & $\begin{array}{l}\text { D } \\
\left(\mathbf{g ~ p o t}^{-1}\right)\end{array}$ & $\begin{array}{l}\text { C } \\
\left(\mathbf{g ~ p o t}^{-1}\right)\end{array}$ & $\mathbf{b}$ & $\begin{array}{l}\mathbf{L D}_{50} \\
\left.(\mathbf{G}) \mathbf{~ h a}^{-1}\right)\end{array}$ & $\begin{array}{l}\mathbf{L D}_{50} \\
\left(\mathbf{J ~ c m}^{-2}\right)\end{array}$ \\
\hline Weeds & Annual & I & 2.51 & -- & 0.98 & 1.23 & 12.3 \\
& bluegrass & II & 11.8 & -- & 0.74 & 11.1 & 111.0 \\
& Common & I & 3.32 & 0.023 & 1.38 & 0.50 & 5.0 \\
& groundsel & II & 17.1 & -- & 0.76 & 6.22 & 62.2 \\
& Small nettle & I & 2.56 & 0.03 & 2.02 & 0.10 & 1.0 \\
& & II & 16.4 & 6.92 & 1.34 & 1.48 & 14.8 \\
& Shepherd's & I & 3.18 & -- & 0.67 & 0.16 & 1.6 \\
& purse & II & 8.94 & 0.86 & 0.97 & 0.5 & 5.0 \\
& Canola & I & 20.7 & 0.25 & 1.24 & 0.75 & 7.5 \\
& Pea & I & 5.45 & 0.45 & 1.07 & 3.13 & 31.3 \\
\hline
\end{tabular}

Table 4.8: Plant response to laser treatment (Modified from: Mathiassen et al., 2006).

\begin{tabular}{|c|c|c|c|c|c|c|c|c|c|c|}
\hline \multirow[t]{2}{*}{ Laser } & \multirow{2}{*}{$\begin{array}{l}\text { Spot } \\
\text { Diameter } \\
(\mathrm{mm})\end{array}$} & \multicolumn{3}{|c|}{ Stellaria media } & \multicolumn{3}{|c|}{$\begin{array}{l}\text { Tripleurospermum } \\
\text { inodorum }\end{array}$} & \multicolumn{3}{|c|}{ Brassica napus } \\
\hline & & b & $\begin{array}{l}\text { LD }_{90} \\
(J)\end{array}$ & $\begin{array}{l}\text { LD }_{90} \\
\left(\mathrm{~J} \mathrm{~mm}^{-2}\right)\end{array}$ & b & $\begin{array}{l}\mathrm{LD}_{90} \\
(\mathrm{~J})\end{array}$ & $\begin{array}{l}\mathrm{LD}_{90} \\
\left(\mathrm{~J} \mathrm{~mm}^{-2}\right)\end{array}$ & b & $\begin{array}{l}\text { LD }_{90} \\
(J)\end{array}$ & $\mathrm{LD}_{90}$ \\
\hline $5 \mathrm{~W}$ & 0.9 & -4.6 & 1.4 & 2.2 & -3.4 & 2.6 & 4.1 & n.e. & $>5.0$ & 7.8 \\
\hline $\begin{array}{l}532 \\
\mathrm{~nm}\end{array}$ & 1.8 & n.e. & $<1.25$ & 0.5 & -5.3 & 2.7 & 1.1 & -4.7 & 10.8 & 4.3 \\
\hline $90 \mathrm{~W}$ & 1.2 & -3 & 58.3 & 51.6 & -5.4 & 44.8 & 39.7 & n.e. & $>90.0$ & 79.6 \\
\hline $\begin{array}{l}810 \\
\mathrm{~nm}\end{array}$ & 2.4 & -0.9 & 104.9 & 23.2 & -3.2 & 73.8 & 16.3 & -1.6 & $>225.0$ & 49.8 \\
\hline
\end{tabular}

Note: n.e. indictaes that this paramater was unable to be evaluated.

Most of the values for $\mathrm{b}$ in Table 4.8 are large, indicating that the slope of the plant response is high; therefore, it is important to apply an energy dose which is higher than the threshold value for $\mathrm{LD}_{90}$, to ensure efficacy. When the various laser energy doses are scaled for comparison to other weed control techniques, a dose of between 50 and $7960 \mathrm{~J} \mathrm{~cm}^{-2}$ of laser energy is required to control $90 \%$ of weeds, depending on the weed species, growth stage, laser power, and laser wavelength, which is more than is needed by some other forms of electromagnetic radiation.

Lasers have the potential to provide weed control; however, the device needs to accurately target the weed plant stems to kill the plant. This is not easily achieved. Various machine vision or scanning techniques are being investigated to provide accurate laser targeting for weed control. These systems are also being used in autonomous agricultural robots. 
Table 4.9: Summary of energy needs for various weed control strategies on a per treatment basis.

\begin{tabular}{ll}
\hline Weed or Soil Treatment System & $\begin{array}{l}\text { Mean energy Requirements for complete coverage } \\
\left(\mathrm{GJ} \mathbf{h a}^{-1} \text { ) }\right.\end{array}$ \\
\hline Steam - soil fumigation & 1,190 \\
Laser & 233.5 \\
Steam - Weed control & 17.7 \\
Tillage & 17.5 \\
Hot water & 14.3 \\
Hand Hoeing & 10.8 \\
Ox drawn tillage & 5.2 \\
Flaming & 3.4 \\
IR & 3 \\
UV & 2.5 \\
Herbicide (Total energy, including embodied & 1.4 \\
energy for manufacture and transport) & \\
\hline
\end{tabular}

\subsection{Conclusions}

All the techniques discussed in this chapter can be used to either control weed growth or kill weeds. Most of the technologies discussed in this chapter require moderate to high energy investment to achieve adequate weed control (Tab. 4.9). Some of these technologies have been commercialised to some degree; however, many of them have not progressed beyond the research phase. As herbicide resistance becomes more prevalent, some, or all, of these technologies may become more widely adopted.

\subsection{References}

Amery, D., Schramm, G., \& Shapiro, K. (1978). Production Systems in Fragile Environments. Paper presented at the Science and Technology for Managing Fragile Environments in Developing Nations.

Andreasen, C., Leif, H., \& Jens, C. S. (1999). The Effect of Ultraviolet Radiation on the Fresh Weight of Some Weeds and Crops. Weed Technology, 13(3), 554-560.

Ascard, J. (1994). Dose-response models for flame weeding in relation to plant size and density. Weed Research, 34(5), 377-385. doi:10.1111/j.1365-3180.1994.tb02007.x

Ascard, J. (1998). Comparison of flaming and infrared radiation techniques for termal weed control. Weed Research, 38, 69-76.

Duke, S. O. (2010). Herbicide and pharmaceutical relationships. Weed Science, 58(3), 334-339.

Fennimore, S. A., \& Goodhue, R. E. (2016). Soil Disinfestation with Steam: A Review of Economics, Engineering, and Soil Pest Control in California Strawberry. International Journal of Fruit Science, 16(S1), 71-83. 
Fore, S. R., Porter, P., \& Lazarus, W. (2011). Net energy balance of small-scale on-farm biodiesel production from canola and soybean. Biomass and Bioenergy, 35(5), 2234-2244. doi:10.1016/j. biombioe.2011.02.037

Gay, P., Piccarolo, P., Ricauda Aimonino, D., \& Tortia, C. (2010a). A high efficacy steam soil disinfestation system, part II: Design and testing. Biosystems Engineering, 107(3), 194-201. doi:http://dx.doi.org/10.1016/j.biosystemseng.2010.07.008

Gay, P., Piccarolo, P., Ricauda Aimonino, D., \& Tortia, C. (2010b). A high efficiency steam soil disinfestation system, part I: Physical background and steam supply optimisation. Biosystems Engineering, 107(2), 74-85. doi:http://dx.doi.org/10.1016/j.biosystemseng.2010.07.003

Gelsomino, A., Petrovičová, B., Zaffina, F., \& Peruzzi, A. (2010). Chemical and microbial properties in a greenhouse loamy soil after steam disinfestation alone or combined with $\mathrm{CaO}$ addition. Soil Biology and Biochemistry, 42(7), 1091-1100. doi:http://dx.doi.org/10.1016/j. soilbio.2010.03.006

Giampietro, M., \& Pimentel, D. (1990). Assessment of the energetics of human labor. Agriculture, Ecosystems \& Environment, 32(3), 257-272. doi:https://doi.org/10.1016/01678809(90)90164-9

Giampietro, M., \& Pimentel, D. (1991). Energy efficiency: Assessing the interaction between humans and their environment. Ecological Economics, 4(2), 117-144. doi:https://doi.org/10.1016/0921. 8009(91)90025-A

Godwin, R. J., O’Dogherty, M. J., Saunders, C., \& Balafoutis, A. T. (2007). A force prediction model for mouldboard ploughs incorporating the effects of soil characteristic properties, plough geometric factors and ploughing speed. Biosystems Engineering, 97(1), 117-129. doi:10.1016/j. biosystemseng.2007.02.001

Gourd, T. (2002). Controlling weeds using propane generated flame and steam treatments in crop and non croplands. Retrieved from Santa Cruz, CA, U. S. A.

Guyton, K. Z., Loomis, D., Grosse, Y., El Ghissassi, F., Benbrahim-Tallaa, L., Guha, N., et al. (2015). Carcinogenicity of tetrachlorvinphos, parathion, malathion, diazinon, and glyphosate. The Lancet Oncology, 16(5), 490-491. doi:10.1016/S1470-2045(15)70134-8

Heap, I. M. (1997). The occurrence of herbicide-resistant weeds worldwide. Pesticide Science, 51(3), 235-243.

Heap, I. M. (2016). International Survey of Herbicide Resistant Weeds. Retrieved from http://www. weedscience.org/

Heisel, T., Schou, J., Christensen, S., \& Anderson, C. (2001). Cutting weeds with a CO2 laser. Weed Research, 41, 19-29.

Hernández, A. F., Parrón, T., Tsatsakis, A. M., Requena, M., Alarcón, R., \& López-Guarnido, O. (2013). Toxic effects of pesticide mixtures at a molecular level: Their relevance to human health. Toxicology, 134-145. doi:http://dx.doi.org/10.1016/j.tox.2012.06.009

Holman, J. P. (1997). Heat Transfer (8th ed.). New York: McGraw-Hill.

Kempenaar, C., \& Spijker, J. H. (2004). Weed control on hard surfaces in The Netherlands. Pest Management Science, 60(6), 595-599. doi:10.1002/ps.863

Kolberg, R. L., \& Wiles, L. J. (2002). Effect of Steam Application on Cropland Weeds. Weed Technology, 16(1), 43-49. doi:10.1614/0890-037X(2002)016[0043:EOSAOC]2.0.CO;2

Lepeschkin, W. W. (1912). Zur Kenntnis der Einwirkung supamaximaler Temperaturen auf die Pflanze. Berichte der Deutschen Botanishen Gesellschaft, 30, 713-714.

Levitt, J. (1980). Response of Plants to Environmental Stresses (Vol. 1). New York: Academic Press.

Mačkić, S., \& Ahmetović, N. (2011). TOXICOLOGICAL PROFILES OF HIGHLY HAZARDOUS HERBICIDES WITH SPECIAL REFERENCE TO CARCINOGENICITY TO HUMANS. Herbologia, 12(2), 55-60.

Mathiassen, S. K., Bak, T., Christensen, S., \& Kudsk, P. (2006). The Effect of Laser Treatment as a Weed Control Method. Biosystems Engineering, 95(4), 497-505. doi:http://dx.doi. org/10.1016/j.biosystemseng.2006.08.010 
Melander, B., \& Kristensen, J. K. (2011). Soil steaming effects on weed seedling emergence under the influence of soil type, soil moisture, soil structure and heat duration. Annals of Applied Biology, 158(2), 194-203. doi:10.1111/j.1744-7348.2010.00453.x

Nishimura, A., Asai, M., Shibuya, T., Kurokawa, S., \& Nakamura, H. (2015). A steaming method for killing weed seeds produced in the current year under untilled conditions. Crop Protection, 71 125-131. doi:http://dx.doi.org/10.1016/j.cropro.2015.02.015

Owen, M., Walsh, M., Llewellyn, R., \& Powles, S. (2007). Widespread occurrence of multiple herbicide resistance in Western Australian annual ryegrass (Lolium rigidum) populations. Australian Journal of Agricultural Research, 58(7), 711-718.

Parish, S. (1990). A review of non-chemical weed control techniques. Biological Agriculture and Horticulture, 7(2), 177-1137. doi:10.1080/01448765.1990.9754540

Peighambarzadeh, S. Z., Safi, S., Shahtaheri, S. J., Javanbakht, M., \& Forushani, A. R. (2011). Presence of Atrazine in the Biological Samples of Cattle and Its Consequence Adversity in Human Health. Iranian Journal of Public Health, 40(4), 112-121.

Price, A., \& Kelton, J. (2011). Weed Control in Conservation Agriculture In M. Larramendy (Ed.), Herbicides, Theory and Applications (pp. 3-16). Rijeka, Croatia: InTech.

Raffaelli, M., Martelloni, L., Frasconi, C., Fontanelli, M., Carlesi, S., \& Peruzzi, A. (2016). A prototype band-steaming machine: Design and field application. Biosystems Engineering, 144, 61-71. doi:http://dx.doi.org/10.1016/j.biosystemseng.2016.02.001

Rask, A. M., Larsen, S. U., Anderson, C., \& Kristofferson, P. (2013). Determining treatment frequency for controlling weeds on traffic islands using chemical and non-chemical weed control. Weed Research, 53, 249-258.

Saunders, C., Godwin, R. J., \& O’Dogherty, M. J. (2000). Prediction of Soil Forces Acting on Mouldboard Ploughs. Paper presented at the 4th International Conference on Soil Dynamics, Adelaide, Australia.

Storeheier, K. (1994). Basic investigations into flaming for weed control. Acta Horticulturae, 372, 195-204.

Tabatabaeefar, A., Emamzadeh, H., Varnamkhasti, M. G., Rahimizadeh, R., \& Karimi, M. (2009). Comparison of energy of tillage systems in wheat production. Energy, 34(1), 41-45. doi:https:// doi.org/10.1016/j.energy.2008.09.023

Troudi, A., Sefi, M., Ben Amara, I., Soudani, N., Hakim, A., Zeghal, K. M., et al. (2012). Oxidative damage in bone and erythrocytes of suckling rats exposed to 2,4-dichlorophenoxyacetic acid. Pesticide Biochemistry and Physiology, 104(1), 19-27. doi:http://dx.doi.org/10.1016/j. pestbp.2012.06.005

Vollmer, M. (2004). Physics of the microwave oven. Physics Education, 39(1), 74-81.

Wickerham, E. L., Lozoff, B., Shao, J., Kaciroti, N., Xia, Y., \& Meeker, J. D. (2012). Reduced birth weight in relation to pesticide mixtures detected in cord blood of full-term infants. Environment International, 47(0), 80-85. doi:http://dx.doi.org/10.1016/j.envint.2012.06.007

Zoz, F. M., \& Grisso, R. D. (2003). Traction and Tractor Performance. Paper presented at the Agricultural Equipment Technology Conference, Louisville, Kentucky USA. 


\subsection{Appendix A}

Determining the peak radiation wavelength for any temperature:

$$
\begin{gathered}
\frac{d \rho}{d \lambda}=\frac{2 c^{3} h^{2} e^{\frac{h c}{\lambda k T}}}{k T \lambda^{7}\left(e^{\frac{h c}{\lambda k T}}-1\right)^{2}}-\frac{10 c^{2} h}{\lambda^{6}\left(e^{\frac{h c}{\lambda k T}}-1\right)}=0 \\
\frac{2 c^{3} h^{2} e^{\frac{h c}{\lambda k T}}}{k T \lambda^{7}\left(e^{\frac{h c}{\lambda k T}}-1\right)^{2}}=\frac{10 c^{2} h}{\lambda^{6}\left(e^{\frac{h c}{\lambda k T}}-1\right)}
\end{gathered}
$$

Rearranging gives:

$$
\lambda=\frac{2 h^{2} c^{3} e^{\frac{h c}{\lambda k T}}\left(e^{\frac{h c}{\lambda k T}}-1\right)}{10 c^{2} h k T\left(e^{\frac{h c}{\lambda k T}}-1\right)^{2}}
$$

Or

$$
\lambda=\frac{h c \cdot e^{\frac{h c}{\lambda k T}}}{5 k T\left(e^{\frac{h c}{\lambda k T}}-1\right)}
$$

At normal temperatures $e^{\frac{h c}{\lambda k T}} \sim 10^{20}$ therefore:

$$
\lambda \approx \frac{h c}{5 k T}
$$

\subsection{Appendix B}

Determining the total radiated power from a black body:

$$
\mathrm{P}=2 \mathrm{hc} c^{2} \int_{0}^{\infty} \frac{1}{\lambda^{5}\left\{\mathrm{e}^{\frac{\mathrm{hc}}{\lambda \mathrm{kT}}-1}\right\}} \cdot d \lambda
$$

Let $u=\frac{\mathrm{hc}}{\lambda \mathrm{kT}} ; \lambda=\frac{\mathrm{hc}}{\mathrm{ukT}}$ and $d \lambda=\frac{-\mathrm{hc}}{\mathrm{u}^{2} \mathrm{kT}} \cdot d u$ 
Substituting into the previous equation gives:

$$
\mathrm{P}=2 \mathrm{hc}^{2} \int_{0}^{\infty} \frac{\frac{-\mathrm{hc}}{\mathrm{u}^{2} \mathrm{kT}}}{\left(\frac{\mathrm{hc}}{\mathrm{ukT}}\right)^{5}\left\{\mathrm{e}^{\mathrm{u}-1\}}\right.} \cdot d u
$$

Rearranging gives:

$$
\mathrm{P}=2 \mathrm{hc}^{2}\left(\frac{k T}{h c}\right)^{4} \int_{0}^{\infty} \frac{\mathrm{u}^{3}}{\left\{\mathrm{e}^{\mathrm{u}}-1\right\}} \cdot d u
$$

Evaluating the integral gives:

$$
\mathrm{P}=2 h c^{2}\left(\frac{k T}{h c}\right)^{4} \frac{\pi^{4}}{15}
$$

Rearranging gives:

$$
\mathrm{P}=\frac{2 \pi^{5} \mathrm{k}^{4}}{15 h^{3} c^{2}} T^{4}
$$

This can be simplified to:

$$
\mathrm{P}=\sigma T^{4}
$$

Where $\sigma$ is the referred to as the Stefan-Boltzmann constant

In the case of a normal object the power transfer is reduced by a factor $\varepsilon$, depending on the properties of the object's surface; therefore, the power transfer is:

$$
\mathrm{P}=\varepsilon \sigma T^{4}
$$

